Atouts et outils de l'ethnologie des techniques

\title{
Sens de la tendance technique
}

Bruno Martinelli

\section{OpenEdition}

Journals

Édition électronique

URL : https://journals.openedition.org/tc/601

DOI : $10.4000 /$ tc. 601

ISSN : 1952-420X

\section{Éditeur}

Éditions de l'EHESS

\section{Édition imprimée}

Date de publication : 1 septembre 1994

ISSN : 0248-6016

\section{Référence électronique}

Bruno Martinelli, «Sens de la tendance technique », Techniques \& Culture [En ligne], 21 | 1994, mis en ligne le 30 décembre 2005, consulté le 29 septembre 2022. URL : http://journals.openedition.org/tc/ 601 ; DOI : https://doi.org/10.4000/tc.601

Ce document a été généré automatiquement le 29 septembre 2022

Tous droits réservés 


\section{Sens de la tendance technique}

Bruno Martinelli 